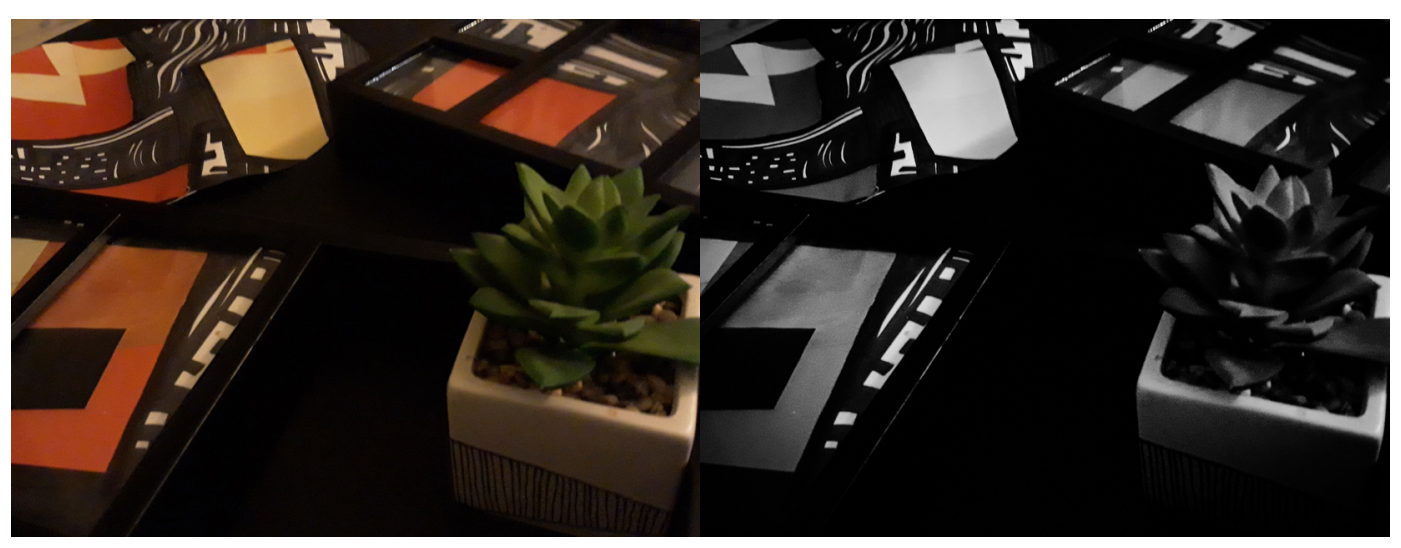

\title{
Módulos de collage lúdico
}

\section{Técnica}

Técnica Mixta. Plumones y materiales reciclados (cartón, impresiones, marcos de fotografía, planta artificial). $110 \times 81 \mathrm{~cm}$.

\section{Reflexión}

\section{Solitud}

El tiempo entreteje espacios

El horizonte gira

Al compás de nuevas experiencias,

Todas válidas

De cara al Sol.

Los módulos habitacionales acercan y alejan la vecindad En largos silencios.

El collage, tablero lúdico

Marca el ritmo de cada día, Cual eco del latido

De nuestro corazón

Aunque la distancia borre

Cualquier encuentro.

Creo mi mundo, a través

De mi universo interno.

Lo disfruto...

\section{Autora}

Lilian Yolanda Rojas rojasgross@um.edu.mx

Montemorelos, Nuevo León, México

Instituto IASE

Arteterapia: papeles de arteterapia y educación artística para la integración social.

Monográfico: Las miradas del arte y el arteterapia en tiempos de la Covid19. ISSN-e: 1988-8309 https://dx.doi.org/10.5209/arte.75899 